\title{
ENVIRONMENTAL BENCHMARKING: A REVIEW OF CONCEPTS
}

\author{
DASSisti, M.; GiAnNOCCARO, R.; LUDOVICO, A.D. \& SCORZIELLO, \\ $\mathrm{F}$.
}

Abstract: Benchmarking is often mentioned as the 'magic tool'to foster competition between enterprises and lead to improvements; one possible commonly agreed definition is as the structured process of learning from others reputed as best performing.

The term benchmarking is used in a broader sense for environmental questions. The key objective of this work is to address the concept of 'environmental benchmarking' and to offer a road map to its different applications starting from the basic definition of performance measurement. A brief review of key concepts about environmental measures is provided as well as an overview of the terms used in this context and of the basic methodology. An analysis of existing and emerging international practices on environmental performance indicators is also discussed. The potential outcomes of this work is a support to the design of environmental benchmarking as a tool to address environmental evaluations in different contexts, either within local communities or manufacturing settings actions towards sustainability management.

Key words: generative programming, generative objects, software reengineering
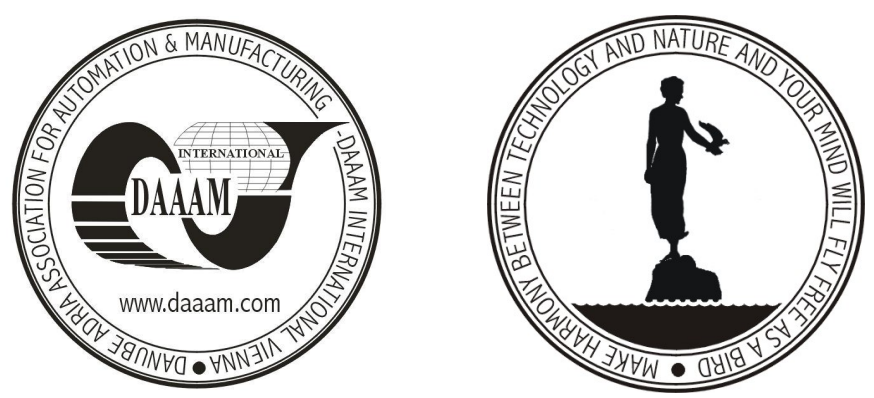

Authors' data: Prof. Ing. Dassisti, M[ichele]; Dr. Giannoccaro, R[osanna]; Prof. Ludovico, A[ntonio] D[omenico]; Dr. Scorziello, F[rancesca], Politecnico di Bari, Dipartimento di Ingegneria Meccanica e Gestionale, V.le Japigia 182, 70126 Bari, Italia, m.dassisti@poliba.it, rgiannoc@poliba.it, ludovico@poliba.it, scorziellof@poliba.it

This Publication has to be referred as: Dassisti, M.; Giannoccaro, R.; Ludovico, A.D. \& Scorziello, F. (2007). Environmental Benchmarking: A Review Of Concepts, Chapter 40 in DAAAM International Scientific Book 2007, B. Katalinic (Ed.), Published by DAAAM International, ISBN 3-901509-60-7, ISSN 1726-9687, Vienna, Austria

DOI: $10.2507 /$ daaam.scibook.2007.40 